\title{
JAVANESE BELIEF IN THE CEREMONY OF BERSIH DESA WITH WAYANG KULIT PLAY
}

\author{
Djoko Sulaksono ${ }^{1}$, Winda Dwi Lestari ${ }^{1}$, Budi Waluyo ${ }^{1}$, Islahuddin ${ }^{2}$ \\ ${ }^{1}$ Universitas Sebelas Maret, Surakarta, Indonesia \\ ${ }^{2}$ Fatoni University, Pattani, Thailand \\ Email: windhalestari@staff.uns.ac.id
}

Received: July 7, 2021

Accepted: November 14, 2021

\section{Abstract}

Humans, nature, culture, and creators have an inseparable relationship. In Javanese culture, gratitude is realized through cultural events, such as Bersih Desa (village clean-ups ceremony). A puppet play of Sri Mulih is performed as an expression of gratitude. This research is a qualitative descriptive study with three stages: data reduction, data presentation, and conclusion drawing. The data source is a video of Wayang Purwa play of Sri Mulih. First, the data are reduced and analyzed by discussing the problem. Finally, the data are assessed by using triangulation techniques to obtain data validity. This study found that the religious value within the play is related to the ceremony of Bersih Desa in the Purworejo district. The finding provides a picture of the acculturation of local culture and Islamic teachings because wayang plays are adapted according to the Javanese culture.

Manusia, alam, budaya, dan pencipta memiliki hubungan yang tidak bisa dipisahkan. Dalam budaya masyarakat Jawa, rasa syukur diwujudkan dengan acara-acara kebudayaan seperti halnya bersih desa. Lakon wayang kulit Sri Mulih yang dipentaskan sebagai perwujudan rasa syukur masyarakat Jawa. Tujuan penelitian ini adalah untuk mendeskripsikan keyakinan religi masyarakat hubungannya dengan kepercayaan bersih desa menggunakan sarana pertunjukan 
wayang kulit purwa dengan lakon Sri Mulih. Penelitian ini adalah penelitian deskriptif kualitatif dengan tiga tahapan penelitian, yaitu reduksi data, sajian data, dan penarikan simpulan. Sumber data dalam penelitian ini adalah video pertunjukan wayang purwa lakon Sri Mulih. Data-data dalam sumber data utama direduksi dan dianalisis dengan pembahasan masalah. Terakhir data-data yang diperoleh diuji dengan menggunakan teknik triangulasi untuk mendapat suatu derajat validitas data. Hasil dalam penelitian ini, ditemukan nilai religius dalam lakon tersebut terkait prosesi bersih desa di kabupaten Purworejo. Hasil ini memberikan gambaran akulturasi budaya lokal dan ajaran Islam karena lakon wayang telah diadaptasi sesuai dengan kultur busaya masyarakat Jawa.

Keywords: Religious Value; Sri Mulih Play; Bersih Desa; Javanese

\section{Introduction}

Humans, nature, culture, religion, and the creator are closely connected. Religion and culture significantly influence the pattern of human life, so these components are interrelated and inseparable (Wijayanti \& Sulaksono, 2019; van Deursen \& van Dijk, 2019). Humans, nature, and the creator hold a dynamic relationship that is always connected and sustainable (Pandin, 2020). The relationship is integrated into cultural traditions that seek to build local wisdom (Eko \& Putranto, 2019).

Local wisdom is a local cultural wealth home to traditions, arts, regional specialties, beliefs, and philosophical values as a guideline believed to accommodate the policies and virtues of personal and community life (Hidayat et al., 2018). Competence, role, function, and philosophy of local wisdom can be presented through performing arts as media for delivering local values aesthetically and culturally accepted by the community (Indrayuda, 2017). The respective artists present local values, messages, and beliefs in performing arts (Goodlander, 2018).

Performing art refers to traditional art performed lively as the aesthetic value of the people's soul (Appelqvist, 2011; Pristiati, 2018). Performing art becomes a medium for conveying messages to the community implicitly through the storyline and the characters. Wayang Kulit is perceived as one of the cultural performing art products of the nation's ancestral heritage. It is highly appreciated as it can combine the arts of literature, painting, music, sculpture, and semiotics (Wardani \& Widiyastuti, 2013), so it becomes a highly aesthetic work. 
Puppet is an artwork made of carved leather, and when exposed to light, a shadow will appear on the screen (Subiyantoro et al., 2020). The shadow is played by a master called Dalang (Jandra et al., 2016; Suhardjono, 2016). Wayang kulit was initially used by Sunan to educate people to know God and guide their morality (Waston, 2018). Today, Wayang Kulit has a broader function for entertainment, education, character building, ethics, behavior, and religious activities (Dahlan, 2012; Rahmawanto \& Rahyono, 2019). The use of performing arts as a medium of da'wah has been practiced since the period of Sunan. It has been massively popular to spread Islamic teachings in Java (Saddhono \& Lestari, 2019).

In terms of axiology, Wayang Kulit performance can be viewed from the aesthetic value and its description in life, including beliefs and moral ethics. Within the shadow puppet show with Sri Mulih's play, we find the religious value related to the ceremony of Bersih Desa in Purworejo district. Sri Mulih's play is included in the Ruwatan play, Sudamala play, Murwakala play, and others. However, what makes Sri Mulih play interesting is that it describes the actual conditions of people's life, between leaders and people. In contrast, other plays tend to be more palace-centric without involving people's figures. In this play, the people are considered essential. Wayang Kulit with the play of Sri Mulih is also known as the Sri Sadhana or Mbok Sri Boyong play.

The three names are coherent as a whole. The play is set in Mahabharata story with acculturation of Javanese culture and Islamic religious values. It is told that Ngamarta, a country, experienced pandemis. A lot of people were sick, and it brought into the unstable economy. In some plays, people call it pageblug mayangkara, in which many people suffer sick, prolonged droughts, expensive food and clothing, crime increases, and so on. Puntadewa, the country leader, together with his brothers, Werkudara, Janaka, Nakula and Sadewa, were concerned about this situation. They thought about various solutions, but they turned in vain. Then, Kresna argued that pageblug occurred because Dwi Sri and Sadhana were no longer in Ngamarta. The people of Ngamarta had lost their life goals. Many of them committed forbidden acts, such as gambling, not worshiping, and forgetting their God. At the same time, Raden Praba Kusuma came, who was the son of Janaka and Dewi Supraba. Raden Praba Kusuma promised to bring Dewi Sri and Sadhana back to Ngamarta as a form of his devotion to his father Janaka.

As the story climax, Raden Praba Kusuma managed to find Dewi Sri. Dewi Sri was being chased by Prabu Ataswara, who wanted to bring her to 
his country. Dewi Sri did not want to go along with Prabu Ataswara because he was arrogant, unwise, and arbitrary. Then, Raden Praba Kusuma and King Ataswara fell into fight. In the end, under the request of Raden Praba Kuusuma and the help of Begawan Gembung Unsirah, Dewi Sri was willing to return to Ngamarta, and in the end Ngamarta became gemah ripah, loh jinawi, cheap in clothing, abundant in food and prosperous.

How is the relationship between the community beliefs in Purworejo and the values promoted in Sri Mulih's play regarding Bersih Desa ceremony? This research explores it through field studies and philosophical religious approaches. It aims to find out the religious beliefs of the Javanese people through Bersih Desa tradition ceremony with the performance of Wayang Kulit Purwa. This indigenous Indonesian cultural product contains Islamic religious values. These values are conveyed implicitly within the art performance, encouraging Javanese to think, reason, and act based on the right teachings.

\section{Method}

This study employed a qualitative descriptive research method. It described society's belief in Piruruh Purworejo village towards the tradition of ruwatan with Wayang Purwa performance, especially Sri Mulih play. Besides, it interpreted the belief with their lifestyles and other social phenomena. The research was conducted from September to October 2020 in the village of Pituruh, Purworejo. The data were adopted from a video of Sri Mulih's play documented directly by the researchers. They were then reduced as needed. After the reduction, they were analyzed by using content analysis techniques. Afterwards, the data that has been analyzed were validated by conducting a literature study and also interviews with the puppeteer of Sri Mulih, Ki Sunarpo Guna Prayitno. The informants were also the local village community so that the flow of the story can be adapted to the village. Ki Sunarpo Guna Prayitna is precisely the right informant because he has always been involved in the previous studies. Thus, the interpretation of the analysis by the researchers could be declared valid.

\section{Finding and Discussion}

Puppet is a shadow or reflection of human nature. It is inseparable from the role of Sunan Kalijaga, one of the most influencing scholars for the spread of Islam in Java. Not only a preacher, he is also an artist and humanist that 
the immersing process of Islamic values in Javanese society happens naturally through assimilation and acculturation (Purwadi, 2003).

Regarding Islam and Javanese culture, there rose a popular term called "penjawaan masyarakat Jawa" (leading Javanese to be more Java) with Islamic values in the era of Sunan Kalijaga. The process of da'wah with acculturation of Javanese culture and Islamic values was very successful as it successfully brought peace with Javanese culture and the previous religions. Therefore, the society reached spiritual harmony and good norms.

The acculturation pattern in Java upholds the values of tepa slira and andhap asor (Suseno 2003). It eventually generated harmonious values between Islam and Javanese culture. One of the acculturation products is Wayang Purwa. The story of Wayang Purwa was initially adapted from the story of Mahabharata and Ramayana from India. In Java, the plays were made according to Javanese and Islamic values. For example, there included the plays of Bhima Suci, Semar Mbangun Kayangan, Sri Mulih, and so on, which could not be found in the original story. This research focuses Sri Mulih play.

\section{Religious value within the Play of Sri Mulih}

Spiritual values are immensely brought into the play of Sri Mulih. In the event of Bersih Desa located in Purworejo, the local community employed wayang as a means of reflection and self-improvement depicted in each scene/ lined by Wayang Purwa with Sri Mulih's play. More detail description is provided as follows:

\section{The Scene of Jejer 1 Negara Ngamarta}

Character: Puntadewa, Werkudara, Janaka, Nakula Sadewa, Baladewa, and Kresna

The gist of the story: Puntadewa and his brothers were worried as Dewi Sri and Sadhana left Ngamarta country without any message. Then, Kresna advised them to do introspection. The two goddesses were likely uncomfortable to live in Ngamarta. Balarama told a country called Pudak Sitegal, led by a giant nation's king but very wise. The state was very prosperous that the two goddesses could have gone there.

As a leader, Puntadewa had done his job to prosper his people. However, when Dewi Sri and Sadhana suddenly left the country, Kresna commanded him to do introspection with his attitude as the following words by the puppeteer:

el Harakah Jurnal Budaya Islam Vol. 23 No. 2, 2021 
Kresna: Kathahing para kawula, boten ngemungaken golonganipun para brahmana, para Pandhita, ewa semanten bok bilih para kulawarga Ngamarta wonten ingkang remenipun keplek kecek lan sapanunggalanipun menika ugi kalebet golonganipun kawula ing Ngamarta ingkang sedaya menika wau kedah rinangkul padha dene tresnane yayi Punta. Sampun ngantos mban cindhe mban siladan. Sinaosa benten suku agami, lan benten kulitipun, sampun ngantos wada winada. Nanging sageda dados bhineka tunggal ika tah hana dharma mangrwa.

(A lot of people do not see it from the Brahmins (high), the pious. Therefore, somebody who likes gambling, playing dice, and is in the lower class even if they are a part of the Ngamarta family. However, in Ngamarta, everything must be embraced. Don't discriminate others. Even though they have different ethnic groups, religions, and skin colors, never let them be ridiculed. Be Bhinneka Tunggal Ika tah hana dharma mangrwa.)

The above words contain Islamic values, that a leader should be fair and not to discriminate particular group. God said, "O David, We have made you a caliph (leader or ruler) on earth, so decide (over a case) among humans fairly, and do not follow your lust" [QS 38: 26]. In another verse, it is stated, "... when you decide a law among people, you should do it fairly...”, [QS 4: 58].

\section{The Scene of Paseban Jawi}

Character: Puntadewa, Patih Nila Taksaka, Werkudra, Baladewa Kresna The gist of the story: Werkudara fought against Patik Nila Taksaka who was rude to Puntadewa, saying he wanted to bring his sisterss wife, Dewi Drupadi. After getting an order and blessing from Puntadewa Raja, his brother, Sabda pandhita Ratu Werkudara immediately chased Nila Taksaka to the town square for a fight.

In the data above, there is a sentence of Pandita Ratu which means that the words spoken by the leader must be obeyed and implemented. It is in line with the concept of Islamic, habluminannas, the relationship among humans, in this context, between leaders and their subordinates, leaders and society. There must be an element of trust, loyalty, and integrity to create harmony and order. As reflected in the following quote:

"Wau ta, sabet byar kat nalika wau, paripurna pangandikanipun prabu puntadewa nglenggahi tembung sabda pendhita ratu, sabda pangucap, pandhita temen, ratu 
wus ngarani. Jleg saking palenggahan dhenta arsa kondur angedaton tinon saking mandrawa, kanthi sesanti mugi tansah manggiha kamulyan."

(Right after speaking, Prabu Putadewa mentioned "Sabda Pandita Ratu". Sabda means speech, Pandhita means earnest, Ratu means command. Immediately, from his seat back to kedaton, seen from a distance. With that motto, always find glory.)

\section{The Scene of Praba Kusuma}

Character: Praba Kusuma, Dewi Sri, Janaka, Begawan Gembung Tanpa Sirah, Prabu Ataswara, Kresna

The gist of the story: Raden Praba Kusuma wanted to serve his father, Arjuna. He was willing to bring the goddess of prosperity, Dewi Sri, back to Ngamarta on the orders of Prabu Kresna. During his search, he met Prabu Ataswara who also wanted to bring Dewi Sri back to his country. However, because Praba Kusuma was the son of Janaka and Dewi Supraba, Dewi Sri chose to go with Raden Praba Kusuma. Prabu Ataswara was then cursed to be a plant pest. Begawan Gembung Tanpa Sirah, the father of King Ataswara and also the father-in-law of Praba Kusuma, felt ashamed for the behavior of Prabu Ataswara. Therefore, he did not want to heed his advice as a parent.

From the scene, we can find Islamic values within, birrul walidain or filial piety to parents. To be respectful to parents is higher than going to war. There are two comparisons presented in the story with Praba Kusuma and Prabu Ataswara and their respective consequences. Praba Kusuma with the intention of mikul dhuwur (filial to) his parents succeeded in bringing Dewi Sri back to Ngamarta. However, Prabu Ataswara who was stubborn and fought against his parents turned into a pest. The personification of pests in this case is something annoying, destructive, and unwelcome.

\section{The relationship between religious values and Javanese Belief in the Ceremony of Bersih Desa}

Religious values have been described previously with the object of leaders, the relationship between humans and other humans, and between children and parents. The three are closely related to the causal relationship, sapa sing nandur bakale ngundhuh, sapa sing temen bakal tinemu (whoever sows seeds will reap, whoever is serious will succeed". The interconnection of the Islamic values is the secondary essence of Bersih Desa activities by displaying 
Wayang Purwa with Sri Mulih's play. However, the researchers find out that the religious values within Sri Mulih's play is gratitude. The following are the parts of interconnectivity created as the result of Islamic value acculturation with Javanese culture.

\section{Feeling Gratitude to Allah}

Dewi Sri as the goddess of farmer symbolizes the prosperity of an area. She must have left Ngalengka for a reason. The play told about it implicitly from her expression as follows:

Dewi Sri Luhwati: Ngger yen mangkono aku tak manggon ing Ngamarta. Titikane mengko yen bumine gandaning arum, kawulane guyup rukun, ana sakjroning katentreman msthi aku bakal ana ing kono ya, ngger. Nanging sumurupa lamun bumine jengkar, akeh dredah, akeh pasulayan, akeh para kawula ingkang minger kiblate, lirwa nggone manembah marang panguwasaning Gusti, ngiwakake kabudayane dhewe mengko ora suwe aku bakal oncat maneh saka Ngamarta."

Dewi Sri Luhwati: Son, I will then live in Ngamarta. The sign will be, if the land smells good, the people are in harmony, and I will always be there in peace. But, please know that if later the land is barren, many problems, many crimes, many people have no guidelines, forget how to worship God, they ignore their own culture, I will soon leave Ngamarta again.

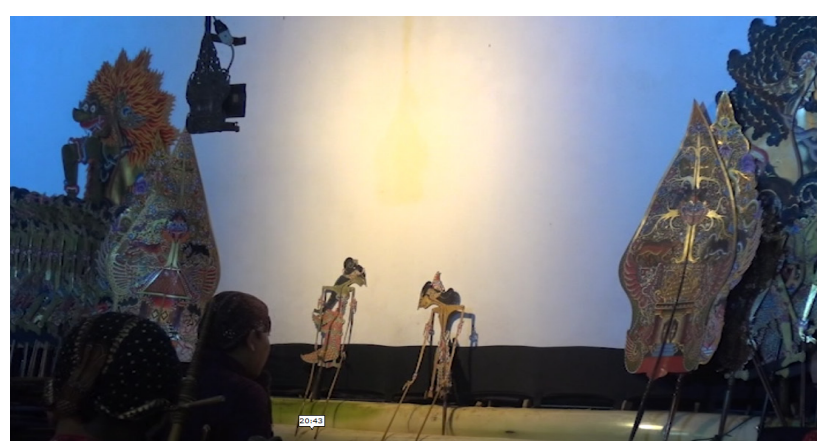

Figure 1 Dewi Sri Luhwati (research documentation)

The above expression implicitly explains that Dewi Sri Luhwati left the Ngamarta because the people had been disgracefully behaved. Many crimes happened, and the most fatal one was leaving God, forgetting worship, and 
ungrateful. They forgot that prosperity was came from Him, who created life, Allah SWT.

The people of Pituruh village, Purworejo, held a ceremony of Bersih Desa with Wayang Purwa play to express gratitude for everything they have obtained so far, especially from the rural agricultural sector. The gratitude was presented as the manifestation of earth alms by giving the harvests to one another. By gratitude, humans have established a good relationship with their God, or the concept of habluminallah in the word of Surah Al Luqman [12] which means: "And indeed, We have given wisdom to Luqman, namely: "Be grateful to Allah. And whoever is grateful (to Allah), indeed he is grateful for himself; and whoever is ungrateful, verily Allah is Rich and Praiseworthy."

\section{Good Relation with Human Beings (Habluminannas)}

Islam has explained that human beings must help and give one another as a form of gratitude. Allah said in Surah Al-maidah [2]: "And help one another unto righteousness and pious duty. Don't help one another unto sin and transgression, but keep your duty to Allah. Allah is severe in punishment. (Q.S Al-Maidah: 2). In the culture of the Javanese community, they already have wiseword that unen-unen pager mangkok luwih becik tinimbang pager tembok (if good neighbors help each other, unity, harmony, conformity and solidity are created in social life.

Wayang Kulit performance becomes a means for the village community to gather in a particular place to watch the performance together. From this matter, Wali (the early Islamic spreader in Java), especially Sunan Kalijaga, still maintain the characteristics of Javanese who like to gather to exchange ideas, thus the relationship between humans with other humans (habluminannas) can always be well maintained, live in harmony with mutual respect. If the relationship between creatures is good, the impact of their relationship with God will also be good. When they watch the performance, they will immediately accept the true mission of Sri Mulih's play. The mind is more open or in Javanese term ngolah rasa.

\section{Reflection of Human Behavior}

Puppet shows are a reflection of human behavior. There should be social problems among society. Even, as individuals, humans have experienced conflict with themselves. The puppet show with Sri Mulih's play describes the story of human life, some of which are good and some are not. Humans are

el Harakah Jurnal Budaya Islam Vol. 23 No. 2, 2021 
expected to be able to distinguish between good and bad. Puppet is a mirror for the audience. It can be seen from the conflicts presented during the show. For example, from a failed war scene, we learn that human sometimes has to fight hard against lust. If they succeed, the reward is happiness symbolized by a scene because it is an amusing entertainment.

Referring to the essence of Bersih Desa, the meaning is to get rid of badness within an individual. In Sri Mulih's play, it is narrated that Dewi Sri left Ngamarta because many people held no guidelines for life and forgot to worship their God. It is a genuine reflection of life that once society loses their religious knowledge guidelines, they will never be prosperous, which might begin with the increase in food and clothing, the increase in crime rate, and so on. Javanese culture upholds harmony in life between humans, humans and nature, and humans and their God, so if a thing happens unproperly, the social system, nature, and religiosity will be disturbed.

\section{Gunungan Wayang Purwa as the Depiction of Universe}

Wayang Purwa performances cannot be separated from ubarampe, the equipment in the show, both the main and the supporting tools. In this study, the researcher will explain the symbolic meaning of gunungan in Wayang Purwa performance. Gunungan, or also called kayon, is derived from the Arabic "Khayu" which means life. It has a vital role in the show. It can be used as a scene transfer, setting support, and a marker of pathet, namely pathet nem, pathet sanga and pathet manyura. The shape of the mountains is also very numerous. There are gunungan sekaten, gunungan gapuran, gunungan blumbangan, gunungan hakikat, and many types of gunungan which can be created by the puppeteer as a supporter of the performance. Each of these mountains has a meaning. The following shows a picture of gunungan gapuran.

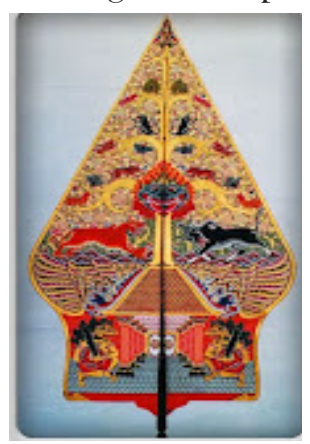

Figure 2 The Picture of Gunungan Gapuran

(Source: Budaya-Indonesia.org)

el Harakah Jurnal Budaya Islam Vol. 23 No. 2, 2021 
Figure 2 is an example of gunungan gapuran. It is commonly used in Wayang Purwa performances, both Gagrak Yogyakarta and Surakarta. The difference between the two Gagrak might be found only in some components of the image.

Gunungan gapuran has main pictures: a house, snake, deer, rooster, monkey, bull, tiger, bird, giant head, two giants/kala, and a lotus flower in a vessel. Each painting in the gunungan gauran has the specific meaning. The omah or house, symbolizes a peaceful life and a beautiful palace. It is mentioned that Baiti Jannati, my house is my heaven. Wherever people go, there must be a comfortable place to go home, namely a house. No matter how good the world is, a house with its contents is a happy place. The 'twin giants', depicted entirely with swords/maces and shields, symbolize the existence of dark and light realms, the natural world, and the unseen world. It is undeniable that they exist. Snakes/dragon, buffalo, bull, monkeys, tigers, patridge, and birds symbolize human lust. Human lust is divided into four, namely amarah, sufiah, aluamah and mutmainah. The lust of amarah or evil is symbolized by the tiger. The lust of sufiah or flow is symbolized with monkeys. The buffalo symbolizes the lust of aluamah or regret, and the lust of mutmainah or wise is symbolized by the painting of birds. Many people call it the bird of garuda.

The image of Ilu-ilu Banaspati as a symbol that in this world there is always danger lurking. Humans must always be watchful, sak beja-bejane wong kang lali isih beja wong sing eling lan waspada 'lucky are those who forget, those are luckier who remember and are always alerted. The image of the ocean, symbolizes human characters as vast as the ocean, is also mentioned in the hasta brata laku hambeging samudra. A leader must have a broad heart and mind to accommodate and realize people's aspirations imposed on him. The four-branched tree of life (pohon hayat), means that humans have a lot of lusts derived from one of the urge mentioned above, amarah, sufiah, aluamah and mutmainah. The lotus flower in a vessel, this symbol cannot be separated from the acculturation of Islamic culture with that of the previous belief, which is Hinduism. The lotus flower symbolizes the balance between water, earth, fire, and wind that must be maintained for the continuity of life in the universe. The shape of gunungan also resembles a mountain. In Javanese symbolism, the mountain embodies manunggaling kawula lan gusti, carrying out religious orders to sharpen the purpose of life, namely Allah.

Javanese were still influenced by animism and dynamism in the early days of the spread of Islam by Wali in Java, especially the era of Sunan Kalijaga 
who acculturated and assimilated Islamic values in Javanese culture in bringing harmony. Therefore, the cultural and Islamic values could go hand in hand with their respective characters without causing significant problems. Even today, the performances of these cultural products are still in great demand.

\section{Ruwatan through the Ceremony of Bersih Desa by Puppet}

Ruwatan is a traditional ceremony to eliminate badness or "sengkala" within individuals or groups of people. The people of Pituruh village believe that through the daily life, they make mistakes, either intentional or unintentional. Therefore, they think that there should be much sin within accumulated so that it is necessary to carry out a cleansing procession or what is known as ruwatan. On the other hand, people who are still influenced by the beliefs of animism and dynamism, which are the teachings of the ancestors of the Javanese think that bad things or sengkala come from evil spirits or evil forces beyond their capabilities.

In the story of Wayang Purwa, there is the term ruwatan. It means cleaning from all impurities. There are three concepts of ruwatan in Javanese society, especially in puppet, namely ruwatan sudamala, ruwatan sukerta, and ruwatan makukuhan. Ruwatan sudamala tells the story of Sadewa care for Bathari Durga back to her original form, namely Dewi Uma. Furthermore, Ruwatan sukerta treats children who are not proper or sukerta, the children are told to be eaten by Bathara Kala. So, it must be done so that the child is protected from catastrophe. Ruwatan makukuhan is usually related to Bersih Desa, which include Sri Mulih's play. It was told that the country of Amarta lost fertility because it was lived by the Goddess of Fertility, namely Dewi Sri, so that Amarta's earth became entangled and nothing could be planted. People were undernourished. Crime happened everywhere. Finally, after Dewi Sri returned to Amarta, the country turned to be fertile, safe, peaceful, prosperous for its people.

With the belief mentioned above, the community needs a means to rid themselves of those bad things. One of them is media puppet, which is personified as a human being. The play used is Sri Mulih, known for Dewi Sri in Javanese, the goddess of fertility. This figure is also known as the incarnation of Dewi Uma. Another opinion also says that Dewi Sri symbolizes a mother and her partner Sadana, which symbolizes clothing or apparel. This cosmology is what the Javanese people believe as the principle of balance. If one of the principles of balance is lost, a treatment is needed to restore the balance. The 
symbolization of the value of balance embraced by the Javanese through Dewi Sri and Sadana is inseparable from the concept of memayu hayuningrat, which maintains a balance of truth, beauty, and the goodness of nature (cosmic) both micro and macro. So, if there found a cause of loss of balance inside a human being, it will affect the balance of the environment.

The concept of memayu hayuningrat cannot be separated from the concept of memayu hayuning bawono (maintaining the balance of the earth)and memayu hayuning raga (of the body). They are illustrated in Sri Mulih's play with the personification of the characters in it, a leaders and people. To maintain the balance of the universe symbolized by the presence of Dewi Sri and Sadana, a leader, in this case the king of Amerta, namely Puntadewa, needs to reflect on some of his policies. A leader, have you been oriented to the interests and welfare of the people? Likewise, whether the people are in an orderly manner in carrying out the policies set by the royal government in the play? If there is an imbalance between the leader and the people, the symbol of balance will disappear. It stops the situation of gemah ripah loh jinawi tata tentrem kerta raharja (orderly, peaceful, prosperous, and sufficient in everything) and becomes an uncomfortable situation. There will be many criminal acts, a crisis of people's trust in the government, and in the end many people become victims.

The personification of Dewi Sri and Sadana as a symbol of balance is also depicted as the goddess of fertility or the goddess of rice. Rice is one of the staple foods for the Javanese people. It is an essential thing in the life of the Javanese people. To harvest rice, people certainly have to take a long process, from seeding, planting, fertilizing, caring, until the harvest. In achieving an essential life balance, Javanese require a process that is not easy, one of which is controlling the lust of amarah, sufiah, and aluamah, so that the lust of mutmainah (goodness) will appear. The lust of amarah, sufiah, and aluamah exists inside humans if the levels are excessive. Then, there is a need for ruwatan to remove the negative things in humans to achieve a balance of life in the universe.

The tradition of ruwatan through Bersih Desa ceremony with Wayang Purwa in Pituruh village is still carried out for a day and night. Wayang Purwa is the event's culmination after previously holding the earth's salvation and cooperation in preparing the event. Apart from its function as ruwatan, Bersih Desa ceremony can also be a means of socializing and helping each other, which is now fading. With this event, the relationship between humans and 
their God is well maintained, and a good relationship of humans with other humans and with the natural surroundings also increases.

\section{Conclusion}

The ceremony of Bersih Desa in the village of Pituruh Purworejo is a manifestation of Javanese culture by acculturation of Javanese culture and Islamic values. The ceremony is conducted in a series of activities. The peak of the event is a puppet show with Sri Mulih's play. The play represents prosperity lost from a country because human relationship with their behavior, nature, and God is imbalance. Prosperity will recur if they can maintain a good relationship with Allah (habluminallah) and other humans (habluminannas). The religious values depicted in Sri Mulih's play manifest human gratitude for the prosperity that God has given. It is what underlies how humans maintain harmonious relationships with other humans and with God. Based on this research, Bersih Desa which is believed as a local wisdom needs to be maintained and developed. Further research may focus on the values of ruwatan tradition as the product of Javanese culture acculturation with Islamic values, or other research related to local wisdom among Javanese society.

\section{References}

Appelqvist, H. (2011). Form and freedom: The Kantian ethos of musical formalism. Nordic Journal of Aesthetics, 22(40-41), 75-88. https://doi. org/10.7146/nja.v22i40-41.5200

Dahlan, B. A. G. (2012). The study of semiotics wayang kulit theatre in Malay culture society. Estudios Sobre El Mensaje Periodistico, 18(1), 321-335. https://doi.org/10.5209/rev_ESMP.2012.v18.n1.39373

Eko, B. S., \& Putranto, H. (2019). The Role of Intercultural Competence and Local Wisdom in Building Intercultural and Inter-religious Tolerance. Journal of Intercultural Communication Research, 48(4), 341-369. https:// doi.org/10.1080/17475759.2019.1639535

Goodlander, J. (2018). Intercultural theatre and community in Southeast Asia: The ASEAN puppet exchange in Jakarta. Asian Theatre Journal, 35(1), 27-52. https://doi.org/10.1353/atj.2018.0011

Hidayat, D., Kuswarno, E., Zubair, F., \& Hafiar, H. (2018). Public Relations Communication Behavior Through a Local-Wisdom Approach: 
The Findings of Public Relations Components Via Ethnography as Methodology. Jurnal Komunikasi Malaysian Journal of Communication, 34(3), 56-72. https://doi.org/10.17576/JKMJC-2018-3403-04

Indrayuda, I. (2017). The Existence of Local Wisdom Value Through Minangkabau Dance Creation Representation in Present Time. Harmonia: Journal of Arts Research and Education, 16(2), 143. https://doi.org/10.15294/ harmonia.v16i2.6146

Jandra, M., Djamil, A. S., Salamon, H., Ansyory, A., \& Zein, M. D. (2016). Identity and Culture Change of Javanese in Johor. Umran: International Journal of Islamic and Civilizational Studies, 3(3-1). https://doi.org/10.11113/ umran2016.3n3-1.140

Pristiati, T. (2018). The Study of Performance Art "Kethuk Roso" by Fenny Rochbeind. Catharsis, 7(2). https://doi.org/10.15294/CATHARSIS. V7I2.24240

Rahmawanto, D., \& Rahyono, F. X. (2019). Strategies for Establishing Harmony in Javanese Face-to-face Dialog in Purwa Shadow Puppet Performances. The Southeast Asian Journal of English Language Studies, 3(1), 115-128. https://doi.org/10.17576/3L-2019-2501-09

Rumambo Pandin, M. G. (2020). Moral-Ethics-Belief Values Towards Indonesian Puppet (Wayang Kulit) Performance Arts. Utopía y Praxis Latinoamericana: Revista Internacional de Filosofía Iberoamericana y Teoría Social, 1(1), 515 521. https://doi.org/10.5281/zenodo.3784909

Subiyantoro, S., Kristiani, K., \& Wijaya, Y. S. (2020). Javanese cultural paradoxism: A visual semiotics study on wayang purwa characters of satria and raseksa figures. Harmonia: Journal of Arts Research and Education, 20(1), 19-28. https://doi.org/10.15294/harmonia.v20i1.23838

Suhardjono, L. A. (2016). Wayang Kulit and The Growth of Islam in Java. Humaniora, 7(2), 231. https://doi.org/10.21512/humaniora.v7i2.3526

van Deursen, A. J., \& van Dijk, J. A. (2019). The first-level digital divide shifts from inequalities in physical access to inequalities in material access. New Media ES Society, 21(2), 354-375. https://doi.org/10.1177/1461444818797082 
Wardani, N. E., \& Widiyastuti, E. (2013). Mapping Wayang Traditional Theatre as A Form of Local Wisdom of Surakarta Indonesia. www. ajssh.leena-luna.co.jp

Waston. (2018). Building peace through mystic philosophy: study on the role of Sunan Kalijaga in Java. IJIMS: Indonesian Journal of Islam and Muslim Societies, 8(2), 281-308. https://doi.org/10.18326/ijims.v8i2

Wijayanti, D. K., \& Sulaksono, D. (2019). Wayang Existence in The Islamization for Traditional Javanese People. El Harakah, 21(1). https:// doi.org/10.18860/el.v21i1.6279 